\title{
Effects of Compensation on Job Satisfaction Among Secondary School Teachers in Maara Sub - County of Tharaka Nithi County, Kenya
}

\author{
Mary Makena Muguongo, Andrew T. Muguna, Dennis K. Muriithi \\ Faculty of Business, Chuka University, Chuka, Kenya \\ Email address: \\ mmakena78@yahoo.com (M. M. Muguongo)
}

\section{To cite this article:}

Mary Makena Muguongo, Andrew T. Muguna, Dennis K. Muriithi. Effects of Compensation on Job Satisfaction Among Secondary School Teachers in Maara Sub - County of Tharaka Nithi County, Kenya. Journal of Human Resource Management. Vol. 3, No. 6, 2015, pp. 47-59. doi: $10.11648 /$ j.jhrm.20150306.11

\begin{abstract}
Compensation plays an important role in determining employees' job satisfaction. According to Bozeman \& Gaughan (2011), the perception of being paid what one is worth predicts job satisfaction. Teachers in Kenya have always downed their tools lamenting about their compensation which raises concern about their job satisfaction. However it is not clear the influence compensation has on teachers job satisfaction to cause the many stand offs. This study therefore sought to establish the effects of compensation on job satisfaction among Secondary school teachers in Maara Sub- County Tharaka Nithi County Kenya. The objectives of the study were to determine the effects of both financial and nonfinancial compensation on job satisfaction. The study employed a descriptive survey research design. Stratified random sampling was used to select a sample size of 214 teachers drawn from the target population of 474 . Responses were collected through administration of questionnaire. The validity and reliability of the questionnaire was enhanced through a pilot study carried out in three schools in Meru South Sub-County. To ensure the validity of the instruments, both face and content validity was used. Data collected was categorized coded and then tabulated using SPSS. The qualitative data was analyzed using descriptive statistics, means frequency tables and percentages. The hypotheses were tested using chi-square. The study established that the basic pay, allowances and work environment affects teachers' job satisfaction to a great extent. The research concluded that teachers were highly dissatisfied with all aspects of compensation that they receive. The study recommends that the government reviews the teachers' compensation to commensurate the services rendered. It is hoped that the findings of this study could assist the education planners in formulating compensation policies that would enable teachers to achieve job satisfaction.
\end{abstract}

Keywords: Allowance, Absenteeism, Basic Pay, Compensation, Job Satisfaction, Retirement Benefits

\section{Introduction}

\subsection{Background of the Study}

In an organization, employees are the key resources through which all the other objectives are achieved. Teachers are the employees of the educational organizations, and their job satisfaction promotes teaching and learning. Employees will demonstrate pleasurable positive attitudes when they are satisfied with their job ( Millan, J. M.et al, 2011). Thus, high job satisfaction will increase the productivity of an organization, in turn increasing the organizational overall performance.

Compensation plays an important role in determining an employee's level of job satisfaction. According to Heathfield
S.M. (2012), compensation is a fixed amount of money paid to an employee by an employer in exchange for a productive work performed. If individuals believe they are not compensated well, a state of emotional dissatisfaction develops. This emotional discrepancy grows and accumulates over time making employees to grumble as they render their service to the organization. Worse still, indicators such as absenteeism, turn over, go slow and strikes are experienced. Compensation has long been considered one of the most important organizational rewards (Heneman \& Judge, 2000) because it allows employees to obtain other rewards (Lawler, 1971). Frederick Taylor (1911) was one of the earliest to recognize the motivating effects of pay when he proposed that workers put forth extra effort on the job to maximize their economic gains. Although this premise lost favor in the 
late 1920s with the emergence of the human relations school (Wren, 1994), money remains the fundamental way that organizations reward employees. Yet, despite the longstanding importance of pay, it impacts on employees job satisfaction remains to be explained. This gives impetus to this study.

According to Bozeman \& Gaughan (2011), the perception of being paid what one is worth predicts job satisfaction. They further state that there is a positive significant relationship between compensation and job satisfaction. Job satisfaction is perceived as an individual's attitude and behavior towards aspects of his own job. Personal job satisfaction is an affective or emotional response toward various facets and outcomes of one's job, meaning that personal satisfaction in relation to a job is not unitary, as a person may be satisfied with one aspect of his or her job and dissatisfied with the rest.

According to Popoola (2007), in the $21^{\text {st }}$ century people pay much attention to their life style and the money they earn from the work than their predecessors. However, it remains unclear whether many of them would continue working, if it were not for the money they receive Employee expectations of a compensation plan are that it is fair and equitable, that it provides them with tangible rewards commensurate with their skills and further, provides recognition and livelihood. Compensation, in today's organizations, is a major consideration in Human Resource Management, and how it is allocated sends a message to employees about what the organizations believe to be important and worth encouraging. For employers, the compensation usually represents a sizeable proportion of operating costs. However, some employers view this only as a cost, while failing to consider the strategic benefits of a well-considered compensation and benefits plan. Compensation therefore, is a critical element of human resources management system, and should be designed to work together with other elements of the system (for instance, organizational goals, professional development, principal leadership, teacher recruitment and selection) to enhance performance. Money not only helps people to attain their basic needs, but it is also instrumental in providing higher level need satisfaction as observed by (Dulebohn \& Werling, 2007).As a result, most employees value work according to how much they gain from it.

In most developing countries, the salary scales for both primary and secondary school teachers are not lucrative despite the rapidly increasing costs of living with very small salary increments awarded based on seniority/experience, with little or no link with actual job performance (Michaelowa, 2002). Further, the teacher's payscale pay is generally very low and declining in real terms as compared to other professionals (Ferguson, 2001). Rural or remote area allowances are paid to teachers, but in general, they are too small to have a major impact on teacher deployment.

In Kenya, teachers are paid a 30 percent rural hardship allowance, but for most teachers, this does not even begin to make up for the additional hardships of rural life (Hyde, Muito \& Muito, 2005).Teachers complain that the system of teacher upgrading is 'haphazard and erratic' and they have to endure extremely poor working conditions. The lack of satisfaction has resulted to rampant absenteeism and turnover (Michaelowa, 2002). This turnover is interpreted as a protest against poor pay. The teachers' salary scheme is laid down by the Teachers Service Commission. The scheme is structured in form of job groups. The higher the job group the better the pay. The job group is determined by factors like the length of service, academic qualifications and other given responsibilities. The teachers' compensation package comprise of the basic pay, house allowance, commuter allowance, medical allowance and hardship allowance for those teachers working in those areas classified as hardship areas (TSC codes of regulation for teachers, 2005). According to Ojwang (2002), many teachers in Kenya complain about the challenges they face in the course of rendering their services. The challenges range from Poor compensation, inadequate resources and heavy work load. These challenges have impacted negatively on the teachers' job satisfaction. This dissatisfaction has been evidenced since independence in various studies (Murithi, 2007). In addition, in a study carried out in Embu County, formerly Embu district, it was found out that teachers were dissatisfied with their terms of service and severally agitated through their recognized trade unions KNUT and KUPPET. Since independence, (1963), teachers in Kenya have gone on strike more than twelve times. The frequency of the strikes has increased since 1997 to almost every year ritual-October 1997, October 1998, October 2002, January 2009, March 2010, September 2011, September 2012, September 2013 and recently in January 2015 (Maara Sub-county Education Records, 2015) It still remains unclear what aspects of compensation have contributed to the rampant strikes, giving impetus to this study. In Maara Sub-County, studies have been carried out mainly on motivation of employees and job satisfaction but none of the studies has been carried out on the effects of compensation on job satisfaction. Therefore, this prompted for research on effects of compensation on job satisfaction among Secondary school teachers in Maara SubCounty.

\subsection{Statement of the Problem}

Compensation has a great impact on productivity. To achieve effective work performance calls for job satisfaction among the workers. In Kenya, there have been a lot of complaints about poor compensation from the teachers. From time to time teachers also walk to the streets to demonstrate against poor compensation. This raises concerns on the effects of compensation on job satisfaction among the teachers. Although there are numerous studies on job satisfaction, no study concerning teachers' compensation has been done in Maara Sub-County. The purpose of this study was to determine the effects of compensation on job satisfaction among secondary school teachers in Maara SubCounty. It was also aimed at establishing whether there were other factors which affect teachers' job satisfaction and recommending ways of making teachers more satisfied. The 
study was guided by the following specific objectives;

i. To establish the influence of basic pay on job satisfaction.

ii. To determine the effects of allowances on job satisfaction.

iii. To establish the effects of working conditions on job satisfaction.

\section{Literature Review}

\subsection{Theoretical Framework}

The theoretical framework used in this study is based on the Expectancy Theory which focuses on link between rewards and behavior. In this study the reward is compensation while the behavior is job satisfaction. According to the theory, Motivation is the product of valence, instrumentality and expectancy. Compensation systems differ according to their impact on these motivational components and pay systems differ most in their impact on instrumentality. There is a perceived link between behavior and pay. Employees reports of their satisfaction with their jobs, are directly related to the extent to which their jobs provide them with such rewarding outcomes, as pay, variety in simulation, consideration from their supervisor, a high probability of promotion, close interaction with co-workers, an opportunity to influence decisions and control over their pace of work (Gupta, 2003). Expectancy theory concentrates on the expectations which employees bring with them to work situation, and the context and manner in which these expectations are satisfied. The underlying hypothesis is that "appropriate levels of effort, and hence productivity, will only be extended if employees expectations are fulfilled". It does not assume a static range of expectations common to all employees but rather points to the possibility of different sets of expectations. Rewards are seen as fulfilling or not fulfilling expectations. Expectancy theory challenges management to demonstrate to employees that extra effort will reap a commensurate reward. The link between effort and reward needs to encompass both the pay packet and a variety of other extrinsic or intrinsic rewards. Reward schemes must therefore create a positive link between the size of the pay packet and the effort expended for employees are primarily motivated by money.

\subsection{The Concept of Compensation}

Compensation refers to all the provided tangible and intangible rewards an employee receives from the employer as part of the employment relationship. The Society for Human Resource Management (SHRM, 2012) has defined compensation as systematic approach to providing monetary value to employees in exchange for work performed. Compensation may achieve several purposes like assisting in recruitment, job performance, and job satisfaction. It can be said that compensation is the "glue" that binds the employee and the employer together in the organized sector, which is further codified in the form of a contract or a mutually binding legal document that spells out exactly how much should be paid to the employee and the components of the compensation package. Rewards and benefits are also type of compensation program that are important for employees (Cascio, 2003). Financially, the salaries must be fair according to employee's contribution. This gives a great sense of ownership and an interesting financial advantage for the employees. Non-financial reward should also be provided to employees for their contributions towards any organizations success (SHRM, 2012).

According to a research report by the Society of Human Resource Management (2012), 6 out of 10 employees indicated that compensation was very important to their overall job satisfaction, putting it only three percentage points below opportunities that use skills and abilities and only one percentage point below job security in 2012. It is further stated compensation, along with job security, has consistently remained on the list of the top five job satisfaction factors most important to employees. As the economic climate continues to warm up and hiring rates increase, attractive compensation packages will be one of the strategies organizations competing for talent will use to recruit and retain the best employees (SHRM, 2012). According to Cascio (2003), the objective of the design of compensation program is divided into two; direct and indirect forms of compensation. Direct compensation has to do with wage or salary aspect while indirect compensation is the fringe benefits a worker enjoys as a result of working in an organization. Integrating the two into a package that will encourage the achievement of an organizations goal is what compensation is all about (Odunlade, 2012). According to McNadimara (2006), compensation includes issues regarding wage and salary programs, structures accruing from job descriptions, merit-based programs, bonus-based programs, commission based programs among others while benefits typically refers to retirement plans, health life insurance, disability insurance, vacation, employee stock ownership among others (Odunlade, 2012).

In the field of management, the key to understanding the process of having a satisfied work force lies in the meaning of the relationship among, needs, drives, and incentives. For as long as organizations have existed, compensation has been recognized as a major motivator of employees as well as an important tool and an expense for organizations. To use compensation as a motivator effectively, human resource managers must consider four major components of a pay structure in an organization (Popoola \& Ayeni, 2007). The components include: job rate, fringed benefits, payment and personal or special allowances. As far back as 1911, Frederick Taylor and scientific management associate described money as the most important factor in motivating the industrial workers to achieve greater productivity (Waren, 1994). Taylor viewed compensation and performance based pay as one of the major tools management had at its disposal to motivate employees and increase their productivity and reduce turn over. In his work, Akitonye (2000) also emphasized that money remains the most important 
motivational strategy. However, even if people were principally concerned with their salaries, this does not prove that money is motivating. There is no firm basis for the assumption that paying people more will encourage them to do better work. This gives a drive to the current study.

According to Sinclair (2002), money possesses significant motivating power in as much as it symbolizes intangible goals like security, power, prestige, and a feeling of accomplishment and success. He also exhibits the motivational power of money with the process of job choice and expounds that money has the power to attract, retain, and motivate employees towards higher performance. For instance, if an employee has another job offer, which offers greater financial rewards and has identical job characteristics with his current job, that worker would most probably be motivated to accept the new job offer (Sinclair 2002). Aswathappa (2005), states that an average employee in the organized sector is entitled to several benefits-financial and non- financial. The financial benefits include wages, salaries, incentives, fringe benefits and perquisites. The non-financial benefits comprise of challenging job responsibility, recognition of merit, growth prospects, competent supervision, comfortable working conditions, job-sharing among others.

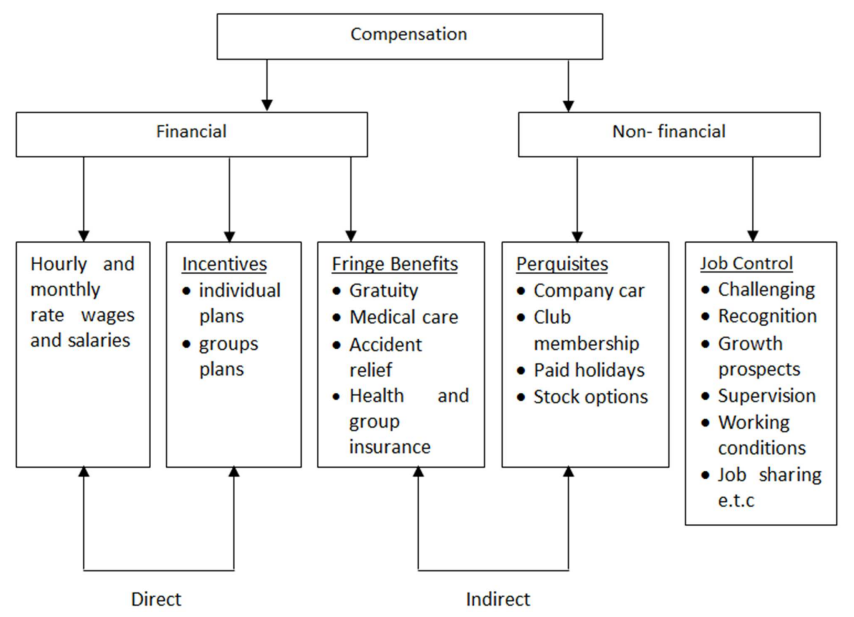

Figure 1. Components of Employee Compensation (Source: Aswathappa, 2005).

\subsection{Components of Compensation}

The following are some components of compensation that have been perceived either to contribute to job satisfaction or dissatisfaction. They include basic pay, allowances, and work environment.

\subsubsection{Basic Pay}

According to Armstrong (2006) the basic pay is the amount of pay that constitutes the rate for the job. The base pay also serves as the benchmarks against which bonuses and benefits are calculated. It may vary according to the grade of the job or the level of skill required and is influenced by internal and external relativities. The internal relativities may be measured by some form of job evaluation while external relativities are assessed by tracking market rates. Other times, levels of pay may be agreed upon through collective bargaining with trade unions or by reaching individual agreements. The base rate may be adjusted to reflect increases in the cost of living or market rates by the organization, unilaterally or by agreement with a trade union. The basic pay is typically used by employees for ongoing consumption. Many countries dictate the minimum base salary defining a minimum wage, individual skills and the level of experience of employees. De Vaney and Chen (2003) identified basic pay as a "hygiene factor" that could cause employee job dissatisfaction if its expectation are not realized. They further found out that basic pay was one of the key elements that significantly influence employees' job satisfaction. Mulvey et al. (2002) further found out that poor pay translated to low job satisfaction, which was in turn related to low degrees of work engagement. In a similar fashion, research on performance appraisal has revealed that sufficient information, in this case on performance-appraisal criteria, increases satisfaction with the performance appraisal system. The model suggests that pay satisfaction depends on the degree of discrepancy between individual's perception of the amounts of pay, that they should receive, and what they actually do receive. Therefore this study seeks to find out some of the pay discrepancies among the teachers, which bring about job dissatisfaction.

\subsubsection{Allowances}

According to Armstrong (2006), employee allowances include pensions, sick pay, insurance cover, company cars and a number of other 'perks'. Perks are used to recognize exceptional contribution, performance, commitment to culture and values. Perks include additional time off, tickets to events, trips, dinners and public recognition. They comprise elements of remuneration additional to the various forms of cash pay and also include provisions for employees that are not strictly remunerated, such as annual holidays. Some benefits are mandated by law, for example social security, unemployment compensation and worker compensation. Besides, benefits can be treated as the payment or entitlement, such as insurance policy employment agreement, or public assistance program. Benefits may also be seen as a reflection of justice in society. Once injustice is perceived then dissatisfaction sets in (Herman, 2005). According to Chiu et al., (2002) rewards/allowances tend to retain people because high reward levels lead to high job satisfaction, commitment, and loyalty. Therefore, when employees feel they are not being rewarded as they expected, it will decrease their job satisfaction leading to low performance. For example, if one perceived fairness about the benefits received from one's employer, this may lead to higher job satisfaction. The use of allowances and rewards varies greatly between countries and professions. Some countries/professions have allowances for certain job types, projects, working hours or regime and location. Other countries, however, have either a holiday allowance or an end-of-year allowance and some have both 
(Adams, 2005). Allowances are primarily tied to organizational financial performance according to the 2006 HR Practices in Executive-Level Compensation Survey Report by the Society for Human Resource Management (SHRM). Most organizations reward top executives for delivering profit growth and increasing revenue. This study focuses on some specific allowances that teachers enjoy which affect their job satisfaction.

\subsection{Working Conditions}

The conditions under which employees work has a tremendous effect on their job satisfaction. According to Desslar (2003) working conditions include aspects like employee voice, employee recognition, quality of the working life, work/life balance, and talent management. The provision of modern equipment and facilities, quality furniture, well ventilated offices, well-spaced offices, secured, well-spaced staff quarters, among others are the conditions that are required to prevent job dissatisfaction in the organization. Therefore, organizations should allow employees to have some input in decision -making that will affect them; establish goals and objectives but let the employees determine how they will achieve those goals and objectives. This study sought to establish the conditions under which the teachers work. Thompson (2002) argues that work environment and personal motivation is the principle of management that dictates how to maximize employee productivity and enhance job satisfaction. A key motivation for employees in a work environment is that each employee is treated fairly no matter what level of input a particular worker has in relation to the institution. Working environment that is comfortable and low of psychological stress facilitates attainment of work goals and tends to produce high levels of satisfaction among the employees. On the other, stressful working environment results to low level job satisfaction. (George and Jones 1999)

According to Heartfield, 2012, most often ignored or forgotten by managers in the workplace is giving an individual employee a sense of worth in relation to the actual work that they have done for the organization. Praise and recognition have been shown to dramatically increase productivity. He further states that maintaining a motivated staff is not always the easiest of tasks, but it does pay off for the organization, customers and the employee. By bringing all employees together for a meeting a team work environment is created (Heartfield, 2012). Working conditions factors have been given considerable attention by researchers because of their impact on job satisfaction. For instance, according to Padilla (1993) unfavourable working conditions in an organization are associated with high rates of employee turnover, which is an indication of job dissatisfaction. On a similar fashion, Ondara (2004) found out that most Kenyan teachers work in deplorable working conditions, a situation that causes a lot dissatisfaction among the teachers. A study done by Mokaya, Wageki and Karanja (2013) on effects of working conditions on employee satisfaction in hotel industry revealed that employee satisfaction is enhanced when an organization provides an employee with training and development opportunities, improvement of working conditions and terms of service. In fact when this is provided employees in these organizations tend to stay longer in service than in cases where employees only look at the fulfillment of organizations objectives without looking at the progress and welfare of the employees (Mokaya, Wageki and Karanja, 2013).This study sought to establish the relationship between the work environment for teachers and job satisfaction.

According to Armstrong (2006), working conditions that are compatible with an employee physical comfort, facilitate doing a good job contributing to job-satisfaction. He further expounds that temperature, humidity, ventilation, lighting, hours of work, cleanliness of the work place, and adequate tools and equipments are the features which affect jobsatisfaction. Hedges (2002), states that most teachers from Sub-Saharan Africa working conditions are poor. He seems to associate these poor working conditions with the notion that teachers are poorly compensated and enjoy limited incentives. However, this study partly negates these findings on the basis that teachers in Maara Sub-County are not the key players in determining the work environment.

\subsection{Job Satisfaction}

According to Hashim, \& Mahmood, (2011) Job satisfaction is an affective reaction to an individual's work situation. It can be defined as an overall feeling about one's job or career and can be related to specific outcomes, such as pay, work environment, job security promotion opportunities among others.. Job satisfaction can be an important indicator of how employees feel about their jobs and a predictor of work behaviors such as organizational citizenship, absenteeism, turnover and overall job performance. Armstrong (2006) defined job satisfaction as the attitudes and feelings people have about their work. Positive and favourable attitudes towards the job indicate job satisfaction. Negative and unfavourable attitudes towards the job indicate job dissatisfaction. Morale is often defined as being equivalent to job satisfaction. Thus Guion (1958) defined morale as the extent to which an individual's needs are satisfied and the extent to which the individual perceives that satisfaction as stemming from his total work situation. Morale and job satisfaction are affected by compensation. Often there is a balance (equity) that must be reached between the monetary values, the employer is willing to pay and the sentiments of worth felt be the employee. In an attempt to save money, employers may opt to freeze salaries or salary levels at the expense of satisfaction and morale. Conversely, an employer wishing to reduce employee turnover may seek to increase salaries and salary levels. Though Maslow's Need Hierarchy Theory talks about compensation being at the middle to lower rank of the pyramid and the other factors like job satisfaction and fulfillment being at the top, for a majority of employees, getting the right compensation is by itself a motivating factor. Hence, employers need to quantify the employee's 
contribution in a proper manner if they are to get the best out of them.

Job satisfaction is important because people who are satisfied have positive feelings about their tasks. It is affected mainly by the challenges and opportunities presented by the work. However, since groups tend to modify the assigned tasks to fit the group structure, job satisfaction is also affected by group factors. According to Middlemist and Hitt (1998) people who are highly satisfied with their job tend to be better workers. Consequently, they are more dependable, comply with the rules, have fewer complains, are more cooperative and efficient. People join and stay in organizations because of rewards from the job. The rewards are either intrinsic or extrinsic. Extrinsic rewards include recognition, enabling work environment among others while intrinsic rewards entail supervision, relationship with co-workers and challenging work opportunities. Borg and Gall (1985), states that job satisfaction is influenced by gender, age, security, experience and recognition. They further state that employees who have more work experience tend to be more satisfied with their jobs than those without experience. Therefore job satisfaction increased with experience. Age and experience in the job usually bring greater competence, self-confidence, responsibility and a sense of accomplishment. According to Schultz (1986) inexperienced workers portray the lowest job satisfaction. This could be attributed to the fact that young workers who are newly employed have un met expectations in terms of compensation and work environment. However, has age catches up on them, and the job opportunities become less, they begin to settle down and derive satisfaction from the only job that is at their disposal. From the teachers point of view this job satisfaction that is achieved as the teacher ages can also be attributed to the fact that the longer the tenure that one serves the higher the basic pay and other benefits.

\subsection{Outcomes of Job Satisfaction}

According Luthans (1989), productivity, absence and turn over are some of the key outcomes of job satisfaction. He states that those employees who are satisfied with their jobs are likely to register high productivity/performance, less absenteeism and very unlikely turn over. On the contrary, Luthan (2002) indicates that there is no strong linkage between satisfaction and productivity/performance and that satisfaction does not lead to performance. For example a comprehensive Meta analysis of the research literature found only a 0.17 average correlation between job satisfaction and productivity. Hence, satisfied workers will not necessarily be the highest performers. This is because there are other possible-mediating factors like rewards altitude, fear of dismissal or an employee may simply work hard to make time go quickly. This relationship between satisfaction and performance gave impetus to this study. Luthans (1989), states that those employees who are dissatisfied are more likely to be absent from work as they take "health" days, off. Employees who choose to be away from work without a good reason are less satisfied than those who register good attendance. Absenteeism is subject to modification by certain factors. The degree to which people feel that their jobs are important has a moderating influence on their absence. Those who feel that their work is important tend to clock in regular attendance. To organizations absenteeism is expensive. Reports of work burn outs, poor health are few among satisfied employees and numerous among the dissatisfied workers. The accumulation of these work burn outs culminates to employee (s) life threatening conditions and sickness which have got cost implications to the organization inform of man hours lost, medical cover usage and other cost associated with employee absenteeism.

On the other hand an employee can be partly absent doing other jobs to supplement what he/she earns. Daun (1997) indicates that when teachers' compensation is so low that their basic needs are not met, they do not give priority to their teaching responsibilities. Consequently, they are pushed to taking second jobs to supplement their income. This study sought to find out whether this applies to teachers in Maara Sub-County. According to Mitchell and Larson (1984) when the satisfaction is high, turnover is low. Turnover is process in which employee leave the organization and have to be replaced. Like absenteeism, turnover is related to job dissatisfaction. Excessive turnover can be a very costly problem with major impact on productivity. For example, in the United State, the national turnover rate for hospital nurses was $12 \%$ in $1996,15 \%$ in 1999 , and $26.2 \%$ in 2000 . Turnover is a serious problem in part because of its relationship to decreased quality of care and creates extra expense for employers (Bozeman \& Gaughan 2011). High employee turnover is of considerable concern for employers because it disrupts normal operations, causes morale problems for those that stick on, and increases the cost involved in selecting and training replacements. The withdrawal behavior of employees is modified by certain factors like loyalty to a particular organization. Some employees cannot imagine themselves working elsewhere, however dissatisfied they are in their present job. Availability of other places of employment also influences turnover. Bozeman \& Gaughan (2011) states that the employer should enhance employee satisfaction to minimize turnover.

\subsection{The Relationship Between Compensation and Job Satisfaction}

Compensation plays a significant role in influencing jobsatisfaction. This is because of two reasons. First, money is an important instrument in fulfilling ones needs; and two; employees often see pay as a reflection of managements' concern for them. Consequently, employees want a pay system, which is simple, fair and in line with their expectations. When pay is seen as fair, based on job demands, individual skill level, and community pay standards, satisfaction is likely to result. According to Bozeman \& Gaughan (2011), the perception of being paid what one is worth predicts job satisfaction. In today's globalized world, organizations are facing changes generated by increased competition, mergers and acquisitions, shifting 
markets and changing employee demographics. Therefore, it is crucial for organization to strategize their competitive and benefits plans in order to attract and retain appropriate talent, maximize return on human capital and increase employees' job satisfaction. A key component for a successful organizational intervention is the meaningfulness of the intervention to the employee. One intervention that may be meaningful to many employees is the amount of their compensation and benefits increase (Mayuri \& Mark, 2005). Compensation is a powerful communicator of organizational goals and priorities and institutions that expect to be successful must make employees become partners in their success (Pam, 2007). She further observes that employee compensation can be a sensitive subject, and people get very passionate compensation issues in an organization. According to the survey report conducted by the Society for Human Resource Management (2012), it was found that compensation and benefits are regularly among the top three factors affecting employee job satisfaction. Although money is not a motivator, employees crave for it because financial independence equates with personal freedom. Hence it is what one does with the money that motivates one to work better. From here, it would seem that compensation and job satisfaction have a positive relationship.

According to March \& Simon (1958), compensation can determine what types of workers are attracted to the organization by signaling job seekers to less visible organizational attributes. The same also determines whether or not employees are willing to continue working for the organization. If the pay level or benefit level is not satisfactory, the desirability of movement will increase and it is more likely that withdrawal behaviors such as tardiness, absenteeism, and turnover increases (March \& Simon, 1958). This study aimed to find out the relationship of some of these behaviours with teachers job satisfaction. Unsatisfactory pay and benefit levels may also reduce the motivation of employees and eventually negatively impact individual, group, and organization performance. Low teacher salaries are a major factor in the high exit rate for new teachers (Carnegie Foundation, 1990; Harris \& Associates, 1992; Ingersoll, 2001; Page \& Page, 1982). It is clear that compensation has been a major factor in teacher turnover for some time, and remedies have not been forthcoming to do anything about it. One could predict from equity theory (Cascio, 2003) that teachers who do not believe that they are compensated equitably for the work and hardships they must endure will take action to remedy the inequity. One of these remedies as cited in the study is leaving the profession.

According to several researchers, compensation and job satisfaction are positively associated with each other. Souza (2000) observes that compensation is a predictor of job satisfaction in that employees who are paid highly show a greater job satisfaction, a view also held by (Joanne, 1980). Employee benefits are used by the organizations to recruit and retain talented employees. In times of economic crisis, when organizations might not be able to offer their employees pay raises and bonuses, benefits become one of the many tools employers use to increase loyalty, productivity and job satisfaction. Based on the survey report conducted by Society for Human Resource Management (SHRM), benefits have remained among the top two most important factors of job satisfaction to employees. Thus, this study aimed at ascertaining these findings.

\section{Methodology}

\subsection{Research Design}

The study employed descriptive survey research design to find out the effects of compensation on job satisfaction among the teachers. According to Orodho (2003), descriptive survey is a method of collecting information by interviewing or administering a questionnaire to a sample of individuals. This design assisted the researcher to obtain important information concerning the status of phenomena and where possible drew general conclusions from the facts discovered. Descriptive survey enabled the researcher to have a systematic collection and presentation of data in order to determine the effects of compensation on job satisfaction among secondary school teachers in Maara Sub-County of Tharaka Nithi County.

\subsection{Sampling Procedures and Sample Size}

Sampling is the process of selecting a biased or random subset of individual observation for the purposes of making projections based on statistical inferences. The sample was drawn from 474 teachers who are currently teaching in 45 secondary schools found in Maara Sub-County. The desired sample size for this study was determined using Kothari (2004) to give a sample of 214 teachers. The study employed stratified random sampling procedure to come up with the respective sample size for secondary school teachers in the Sub-County.

Table 1. Sampling Matrix.

\begin{tabular}{lll}
\hline Job Group & Population & Sample \\
\hline J & 26 & 12 \\
K & 87 & 39 \\
L & 142 & 64 \\
M & 157 & 71 \\
N & 57 & 26 \\
P & 5 & 2 \\
Total & 474 & 214 \\
\hline
\end{tabular}

Source: Maara Sub-County Education Office (2014)

\subsection{Research Instruments}

The research instrument that was used for data collection was questionnaire. The questionnaire which was divided into three parts has per the research objectives, was administered through drop and pick method. The questionnaire was used for data collection because it offers considerable advantages in the administration: it presents an even stimulus potentially to large numbers of people simultaneously and provides the investigation with an easy accumulation of data (Borg \& 
Gall, 1989). Questionnaires give respondents freedom to express their views or opinion and also make suggestions (Gay, 1992).

\subsection{Data Collection Procedure}

The researcher obtained an introduction letter from Chuka University to obtain a research permit from the National Council for Science and Technology. Second, the researcher obtained an introduction letter from the District Education Officer, Mara Sub-County to carry out research in the area. Third, the researcher booked appointments with the principals of the sampled schools to visit and administer the questionnaire. Fourth, the researcher visited each of the sampled schools and administered the questionnaires to the sampled respondents in person. The respondents were assured of confidentiality and given the guidelines on how to respond. This procedure made it possible for the study to achieve representation from teachers in all job groups.

\subsection{Data Analysis}

Data collected from the field was organized in a systematic manner that facilitated analysis. Quantitative data in the questionnaire was coded then transferred to a computer sheet that was prepared using Statistical Package for Social Sciences Software (SPSS). Data from this study was analyzed by the use of descriptive statistics, by calculating percentages, frequencies and means. Data was presented using frequency tables. Bell (1993), states that descriptive statistics is easily understood by a variety of readers unlike complex statistics. The significance levels of the relationship between these variables were analyzed using the chi-square statistics. The reason for using Chi Square was the categorical nature of the data for which Chi Square is an appropriate test. In addition, Chi Square is based on the premise that it is most frequently used to test the statistical significance of results reported in bivariate tables (ConnorLinton, 2001).

\section{Empirical Results and Discussion}

\subsection{Response Rate}

An item was included on the questionnaire which sought information on respondents' response rate. This information is represented on the table below.

Table 2. Response Rate.

\begin{tabular}{llll}
\hline Category & Target & Responses & Response Rate (\%) \\
\hline Principals & 45 & 42 & 93.33 \\
Teachers & 169 & 155 & 91.72 \\
Total & 214 & 197 & 92.03 \\
\hline
\end{tabular}

Out of the 214 questionnaires distributed, a total of 197 questionnaires were duly filled representing $92.03 \%$ response rate. This was an acceptable rate and could be attributed to the fact that the questionnaires were physically delivered to the respondents through drop and pick method.

\subsection{Teachers Compensation}

The study sought to establish the teachers' level of job satisfaction with their compensation. Items were included in the respondents' questionnaire to establish their level of satisfaction. Table 10 presents information on the teachers' level of satisfaction or dissatisfaction.

Table 3. Extent That Compensation Gives Teachers Satisfaction in their Job.

\begin{tabular}{lll}
\hline & Frequency & Percentage \\
\hline Very great extent & 3 & 1.5 \\
Great extent & 11 & 5.6 \\
Moderate extent & 78 & 39.6 \\
Little extent & 96 & 48.7 \\
Not at all & 9 & 4.6 \\
Total & 197 & 100.0 \\
\hline
\end{tabular}

On the extent that compensation gives teachers satisfaction with their job, majority $(48.7 \%)$ of the teachers said compensation gives them satisfaction with their job to a little extent, $39.6 \%$ said to a moderate extent, $5.6 \%$ said to a great extent, $4.6 \%$ said it does not satisfy them at all while a partly $1.5 \%$ of the respondents said compensation gives them satisfaction with their job to a very great extent. The research revealed that none of the teachers was highly satisfied with the compensation that they receive in relation to the work load and their job group compared to other workers with similar qualifications and job group but in different fields. This explains why they are involved in a series of strikes as they perceive inequity in the way they are compensated.

\subsection{Basic Pay and Job Satisfaction}

Items were included in the respondents' questionnaire which sought information on the level of teachers the information is presented on table 11 below.

Table 4. Respondents' Degree of Satisfaction with Selected Facets of Basic Pay.

\begin{tabular}{lll}
\hline & Mean & Std Dev \\
\hline Basic pay & 3.8824 & 1.09447 \\
Timely payment of salary by TSC & 2.2059 & 0.41043 \\
Amount of annual increment awarded & 3.7059 & 0.87141 \\
Pay differences among job groups & 1.6765 & 0.09325 \\
Pay compared to similar jobs in other institutions & 1.8647 & 0.85489 \\
The salary you receive in relation to your job & 2.7353 & 0.89811 \\
group & 4.2588 & 0.77621 \\
Pay compared to similar jobs in other institutions & 4.7059 & 0.97014 \\
\hline The amount of salary in relation to your work load & 3.70 \\
\hline
\end{tabular}

According to the study, majority of the respondents were moderately satisfied with pay structure as shown by a mean score of 1.6765 , pay policy consistency as shown by a mean score of 1.8647 , the way pay is administered to them as shown by a mean score of 2.0588 and pay administration/ timely payment of salary by TSC as shown by a mean score of 2.2059. Majority of the respondents were however slightly satisfied with pay differences among job groups as shown by a mean score of 2.7353 while they were not satisfied with amount pay raise/increase/ amount of annual increment awarded and the amount of salary in relation to their work 
load as shown by a mean score of 3.7059 in each case, basic salary as shown by a mean score of 3.8824 and pay compared to similar jobs in other institutions as shown by a mean score of 4.2588. The findings imply that poor compensation is a major cause of teachers' dissatisfaction as they perceive inequity from the services they render and what they receive in return. According to a similar research carried out by Bessalt (1992) salary was pointed out as one of the key components of teachers' satisfaction. Pay satisfaction makes the teachers to be more involved in their work posting better school performance. When dissatisfaction sets in emanating from pay, there is the likelihood of turn over.

\subsection{Allowances and Job Satisfaction}

The study also wanted to establish the extent that various allowances affect job satisfaction. Items were included in the respondent's questionnaire which sought information on some of the allowances that the teachers receive. Table 12 presents information on allowance in relation to job satisfaction.

Table 5. Extent to Which Allowances Affects Job Satisfaction

\begin{tabular}{lll}
\hline & Mean & Std Dev \\
\hline House allowance & 1.5824 & .69695 \\
Over time pay & 3.3529 & .59708 \\
Transport/ Commuter allowance & 2.8647 & .85489 \\
Hardship allowance & 1.7647 & .81868 \\
\hline
\end{tabular}

From the study findings, majority of the teachers indicated that the allowances that affect job satisfaction to a great extent include house allowance and hardship allowance as shown by a mean score of 1.5824 and 1.7647 respectively. The respondents also indicated that the allowances that affect job satisfaction to a moderate extent include transport/ commuter allowance as shown by a mean score of 2.8647 , and overtime pay as shown by a mean score of 3.3529 . The studies revealed that teacher were satisfied with the allowances depending on the amount. The most satisfaction was derived from house allowance which is awarded the highest amount and the least was commuter which is awarded the least amount. A similar study conducted by Uppal (2005) had a similar out come in that the greater the allowance the higher the job satisfaction and the lower the allowance the lesser the job satisfaction. The alignment of these two trends continues to suggest that benefits impacts significantly on teachers' job satisfaction.

\subsection{Insurance Cover and Job Satisfaction}

The study also wanted to establish the extent that various insurance covers affect job satisfaction among teachers. Items were included in the respondents questionnaires. Table 13 presents the information on various facets of Insurance cover and Job Satisfaction.

From the study findings, majority of the respondents indicated that medical insurance affect job satisfaction among teachers to a very great extent as shown by a mean score of 1.3776 , dental benefits affect job satisfaction among teachers to a great extent as shown by a mean score of 2.2755 while life insurance affect job satisfaction among teachers to a moderate extent as shown by a mean score of 2.7347 .

Table 6. Extent to which Facets of Insurance Covers Affects Job Satisfaction.

\begin{tabular}{lll}
\hline Description & Mean & Std. Deviation \\
\hline Medical insurance & 1.3776 & 0.68135 \\
Dental benefits & 2.2755 & 0.58821 \\
Life insurance & 2.7347 & 0.91720 \\
\hline
\end{tabular}

\subsection{Bonuses and Job Satisfaction}

The study further sought to find out the extent that bonuses affect job satisfaction among teachers. Items were included in the respondents' questionnaire to assess their level of satisfaction with various bonus facets.

Table 7. Extent that Bonuses Affect Teachers Job Satisfaction.

\begin{tabular}{|c|c|c|}
\hline Description & Mean & $\begin{array}{l}\text { Std } \\
\text { Dev }\end{array}$ \\
\hline $\begin{array}{l}\text { The receipt of performance-based rewards, including } \\
\text { pay increases and bonuses, positively affected pay- } \\
\text { system reactions and therefore satisfaction. }\end{array}$ & 1.9306 & 0.78915 \\
\hline $\begin{array}{l}\text { The performance bonus makes me care more about } \\
\text { teaching well }\end{array}$ & 1.3302 & 1.34840 \\
\hline Performance is adequately rewarded & 3.5070 & 1.23705 \\
\hline Pay incentives motivate me & 1.5824 & 1.09447 \\
\hline Pay incentives schemes' objectives are achievable & 2.2059 & 0.41043 \\
\hline $\begin{array}{l}\text { My organization's incentive scheme makes me work } \\
\text { harder }\end{array}$ & 2.7059 & 0.87141 \\
\hline The incentive performance measures are achievable & 2.3941 & 1.43082 \\
\hline $\begin{array}{l}\text { Perception of pay-for-performance is a positive } \\
\text { influence on pay satisfaction. }\end{array}$ & 1.5010 & 0.74874 \\
\hline
\end{tabular}

On the level of agreement with statements on the effects of bonuses on job satisfaction, majority of the teachers strongly agreed that the performance bonus makes them care more about teaching well as shown by a mean score of 1.3302 . The teachers were also in agreement that perception of pay-forperformance is a positive influence on pay satisfaction as shown by a mean score of 1.5010 , pay incentives motivate them as shown by a mean score of 1.5824 , the receipt of performance-based rewards, including pay increases and bonuses, positively affected pay-system reactions and therefore satisfaction as shown by a mean score of 1.9306 , pay incentives schemes' objectives are achievable as shown by a mean score of 2.2059 and the incentive performance measures are achievable as shown by a mean score of 2.3941 . The teachers were however neutral on the fact that their organization's incentive scheme makes them work harder as shown by a mean score of 2.7059 and disagreed with the fact that performance is adequately rewarded as shown by a mean score of 3.5070 .

\subsection{Working Conditions and Job Satisfaction}

On the extent to which various aspects of nonfinancial compensation affects job satisfaction among teachers, the teachers alluded that to a very great extent, their satisfaction is affected by psychic rewards (acknowledgement of teaching competence) as shown by a mean score of 1.5882 , reasonable 
work load as shown by a mean score of 2.4302 and administrative support as shown by a mean score of 1.1072 . The teachers further indicated that the factors that affect their satisfaction to a great extent include in-service course and learning opportunities as shown by a mean score of 2.0412, positive feedback as shown by a mean score of 1.3647 , meaningful and varied work as shown by a mean score of 1.6765 , free/subsidized meals and refreshments as shown by a mean score of, challenging opportunities as shown by a mean score of 1.5765 , task autonomy, participatory decisionmaking as shown by a mean score of 1.4706 and paid holidays as shown by a mean score of 1.2118 . Working conditions factors have been given considerable attention by researchers due to their impact on job satisfaction. For instance, Padillia(1993) argues that unfavourable working conditions in an organization are associated with high rates of employee turnover, which is an indicator of job dissatisfaction. In a study based on five Francophone countries (Burkina Faso, Cameroon, Cote d'lvoire, Madagascar and Senegal), Michaelewa (2002) found that unmanageable class sizes, and inadequate school resources negatively correlated with teachers job satisfaction.

Table 8. Extent that Working Conditions Affect Teachers Job Satisfaction.

\begin{tabular}{lll}
\hline Description & Mean & Std Dev \\
\hline Free/Subsidized meals and refreshments & 1.8235 & 0.93649 \\
Paid Holidays & 2.1765 & 1.05803 \\
Challenging opportunities & 1.8471 & 1.30575 \\
Free/Subsidized meals and refreshments & 1.5765 & 1.09325 \\
Paid Holidays & 1.2118 & 1.23381 \\
Challenging Opportunities & 1.8176 & 0.32703 \\
In-service course and learning opportunities & 2.0412 & 1.01328 \\
Psychic rewards(acknowledgment of teaching & 1.5882 & 0.65679 \\
competence) & 1.6765 & 0.68404 \\
Meaningful and varied work & 1.4706 & 0.56329 \\
Task autonomy and participatory decision-making & 1.3647 & 0.81868 \\
Positive feedback & 1.1072 & 1.23705 \\
Administrative support & 2.4302 & 1.34840 \\
\hline Reasonable work load & & \\
\hline
\end{tabular}

\subsection{Hypotheses Testing}

Hypothesis 1: Basic Pay

Null: Teachers basic pay has no effect on job satisfaction Alternate: Teachers basic pay affects job satisfaction

The null hypotheses imply that the variable- basic pay and teachers' job satisfaction are independent of each other. The researcher wanted to find out whether there was any notable relationship between basic pay and teachers' job satisfaction. The frequency table below shows how the responses on the relationship between basic pay and teachers' job satisfaction were distributed.

Table 9. Chi-Square Tests for Basic Pay and Job Satisfaction.

\begin{tabular}{llll}
\hline & Value & df (degree of freedom) & p-Value \\
\hline Chi-square & 2.734 & 5 & 0.023 \\
\hline
\end{tabular}

The calculated Pearson Chi-Square value is 2.73. The associated P-Value (Asymptotic significance) is 0.023 . This value is less than 0.05 ( $5 \%$ level of significance) indicating that there is evidence against the null hypotheses and therefore we reject it. Basic pay is one of the drives that affect teachers' job satisfaction. It implies therefore that if teachers basic pay is competitive enough, they will be satisfied and motivated to foster improved performance (Bennel, 2007). The findings imply that low basic salary is a major cause for teachers' job dissatisfaction. A conclusion can be drawn from the study that 'Basic pay affects teachers' job satisfaction.

\section{Hypothesis 2: Salary Allowances}

Null: Teachers total allowances have no effect on job satisfaction

Alternate: Teachers total allowances affect job satisfaction

The null hypothesis indicates that both variables - salary allowances and teachers satisfaction are independent of each other.

Table 10. Chi-Square Tests for Salary Allowances and Job Satisfaction.

\begin{tabular}{llll}
\hline & Value & Df & p-Value \\
\hline Chi-Square & 6.536 & 198 & 0.0373 \\
\hline
\end{tabular}

The Pearson Chi-square Value was 6.5 and the associated P- value (Asymptote Significant Value) was 0.0373 . This value is less than 0.05 indicating that there is evidence against the null hypotheses and therefore we reject it. The result correlates Uppal (2005), who found that the allowances employees received were positively related to job satisfaction. This does not agree with Odunlade (2012), who found that a there was no significant relationship between allowances and job satisfaction.. A conclusion can therefore be drawn that salary allowances affect teachers' satisfaction.

Hypothesis 3: Working Conditions

Null: Teachers working conditions have no effect on job satisfaction

Alternate: Teachers working conditions affects job satisfaction

The null hypotheses imply that the variable- Working conditions and job satisfaction are independent of each other. The researcher wanted to find out whether there was any notable relationship between working conditions and job satisfaction. This agrees with Odunlade (2012), who found that a there was no significant relationship between working conditions and job satisfaction. A conclusion can therefore be drawn that working conditions affect teachers' job satisfaction.

Table 11. Chi-Square Tests for Working Conditions and Job Satisfaction.

\begin{tabular}{llll}
\hline & Value & df (degree of freedom) & p-Value \\
\hline Chi-square & 2.942 & 198 & 0.045 \\
\hline
\end{tabular}

The calculated Pearson Chi-Square value is 2.94. The associated P-Value (Asymptotic significance) is 0.045 . This value is less than 0.05 (5\% level of significance) indicating that there is evidence against the null hypotheses and therefore we reject it. A conclusion can be drawn from the 
study that 'Working conditions affect job satisfaction'

\section{Conclusion and Recommendation}

\subsection{Conclusion}

Compensation is one of the drives that motivate workers. From this study it can be argued that if teachers are compensated well, they will be encouraged, assured and will have positive feelings towards their job and this would result to job satisfaction. This is also shared by (Bennel, 2007). The findings imply that poor compensation is a major cause of teachers' job dissatisfaction.

From the findings the study concludes that the compensation the teachers receive does not match their job description. It was deduced that the basic pay teachers receive affects their job satisfaction to a moderate extent including the pay structure, policy consistency, administration and timely payment of salary by TSC. The study also concludes that the allowances such as house allowance and hardship allowance that the teachers received affect their job satisfaction.

Majority of the teachers in secondary schools are holders of Bachelors degree. This implies that under the current scheme of service for graduate teachers the non-graduate teachers cannot benefit. This brings disparity in teachers' salary because of the different levels of education. Thus, those who cannot fit in the scheme feels dissatisfied with their job.

The study further concludes that insurance cover greatly affects job satisfaction among teachers. It was deduced that they are greatly satisfied with medical insurance. The bonuses only affect the job satisfaction of teachers slightly. The performance bonus makes teachers care more about teaching well, pay incentives motivate them and pay incentives schemes' objectives are achievable. The study finally concludes that the nonfinancial compensation that affect the teachers satisfaction include psychic rewards (acknowledgement of teaching competence), reasonable work load and administrative support.

The amount of compensation the teachers receive in comparison to that of their counter parts in the civil service and the allowances given to the teachers are some of the major factors that influence teachers' job satisfaction. Therefore the government should address teachers' compensation issues in order to enhance teachers job satisfaction.

Based on the findings of the study, it can be concluded that teachers in Maara Sub-County are not well compensated and as a result they are dissatisfied.

\subsection{Recommendations}

Based on the findings of the study of the study, the researcher recommends that:

Teachers' basic pay and allowances should be reviewed by The Teachers Service Commission from time to time to reflect changes in the economic landscape of the country.
The school Board of Management and the community should work hand in hand to improve working conditions in the school. This can be done by ensuring that teachers have access to information, free meals and refreshments, adequate teaching and learning resources, preparatory rooms/offices and enabling work environment.

The Board of management and PTA as management organs of the school should recognize and offer compensation incentives to performing teachers to enhance their job satisfaction.

\section{Acknowledgement}

Special thanks to the Almighty God for His all-round protection throughout the entire period of this research. I am highly indebted to Andrew T. Muguna and Dennis Muriithi for their worthy guidance and supervision to the very end.

\section{References}

[1] Adams, J. S. (2005), Inequity in Social Exchange, in Berkowitz, L. (Eds), Advances in Experimental Psychology, Academic Press, San Diego, CA, Vol. Vol. 2 pp.267-99.

[2] Akintoye, I. R. (2000). The Place of Financial Management in Personnel Psychology. A Paper Presented as Part of Personnel Psychology Guest Lecture Series Department of Guidance and Counseling, University of Ibadan, Nigeria.

[3] Asia One, (2012). Singapore second lowest globally for job satisfaction: Survey http://www.asiaone.com/Business/News/Office/Story/A1Story 20120307-32179.html

[4] Aswathappa, M. (2005). The Impact of Teachers' Demographic Characteristics on the Level of Job Satisfaction in Secondary Schools in River State: A Case Study of Teachers in Rivers State Secondary Schools. Unpublished Master Thesis, Port Harcourt: University of Port Harcourt, Nigeria.

[5] Beauregard, T. A \& Henry, L.C. (2009). Making the Link between Work-Life Balance Practices and Organizational Performance, Human Resource Management Review, Vol. 19 No.1, pp.9-22.

[6] Borg, M. G., \& Gall, J. M. (1985). Stress and Job Satisfaction among Primary School Teachers in Malta. Education Review, 41, 271-279.

[7] Bozeman, B. \& Gaughan, M., (2011). Job Satisfaction among University Faculty: Individual, Work, and Institutional Determinants. Journal of Higher Education, 82(2), 154-186

[8] Bunning, R. L. (2004), Pay in the Organic Organisation, Journal of Management Development, Vol. 23 No.7, pp.64863.

[9] Cascio, W. F. (2003). Managing human resources: Productivity, Quality of work, life, Profits. 6th ed. New-York: McGraw Hill Higher Education

[10] Clark, A. E, Oswald, A. J. (2006), Satisfaction and Comparison Income, Journal of Public Economics, Vol. 61 pp.359-81. 
[11] Connor-Linton, J. (2001). Chi Square Tutorial. Retrieved May, 12, 2007, from Http://www.Georgetown.edu/cball/webtools/web_chi_tut.html.

[12] Daun, H. (1997). Teachers' Needs, Culturally Significant Teacher Education and Education Achievement in an African context: The Case of Guinea Bissau. International Journal Education.

[13] DeVaney, S, A., \& Chen, Z. S. (2003). Job Satisfaction of recent graduates in Financial services, US Department of Labour, Bureau of Labour Statistics, Compensation and Working Conditions.

[14] Dessler G. Human Resource Management (5th Ed.)[M]. New York: Prentice- Hall, Inc., 2000

[15] Dreher, G. F. (2008). Predicting the Salary Satisfaction of Exempt Employees, Personnel Psychology, Vol. 34 pp.579-89.

[16] Dulebohn, J. H., Werling, S. E. (2007). Compensation Research Past, Present and Future, Human Resource Management Review, Vol. 17 No.2, pp.191-207.

[17] Eagly, A. H. (1987). Sex Differences in Social Behaviour: A Social-Role Interpretation. Hillslade, NJ: Erlbaum.

[18] Ferguson, A. (2001). Motivating Community-Based Distributors in Kenya. GTZ,

[19] Githinji, A. M (2010). Factors Influencing Secondary School Teachers Job Satisfaction in Runyenjes Division, Embu East District, Kenya. Unpublished M. Ed. thesis in Educational Management, Chuka University College.

[20] Gupta C. B. (2003). Human Resource Management Sultan Chard and Sons Educational Publishers New Delhi.

[21] Hashim, R., \& Mahmood, R. (2011). What Is The State Of Job Satisfaction Among Academic Staff At Malaysian Universities? Unitar E-Journal, 7(1), 15-26.

[22] Heathfield, S. M. (2012). Salary. Retrieved on 1 September 2012 from http://humanresources.about.com/od/glossarys/g/salary.htm

[23] Heneman, H. G. \&, Judge, T.A. (2000), Compensation Attitudes, Compensation in Organizations, Jossey-Bass, San Francisco, CA, pp. 61-

[24] Herman, A. (2005). Performance Management, London: Prentice Hall 103.

[25] Hyde, K., Muito, M. \& Muito G. (2005). Teacher Motivation and Incentives in Kenya, Nairobi.

[26] Ifinedo, P. (2003). Employee Motivation and Job Satisfaction in Finnish Organizations: A Study of Employees in the Oulu Region, Finland. Master of Business Administration Thesis, University of London.

[27] Ilgen, D. R. \& Pulakos, E. D. (1999). Introduction: Employee Performance in Today's Organization, in Ilgen, D. R., Pulakos, E. D. (Eds), The Changing Nature of Performance: Implications for Staffing, Motivation, and Development, Jossey-Bass, San Francisco, CA, pp. 1-18.

[28] Joanne. M. (1980). Individual and Occupational Determinants of Job Satisfaction, Work and Occupations, pp. 337-366.

[29] Johnson, J \& Stears, C. (2005). On the use of 'Intent to...' variables in organizational research: an empirical and cautionary assessment, Human Relations, Vol. 52 No.10, pp. 1337-50.

[30] Kathuri, N. J \& Pals D. A. (2003). Introduction to Educational Research. Njoro, Kenya: Egerton University.

[31] Lawler, E. E (2000). Strategic Pay, Jossey-Bass, San Francisco, CA,

[32] Locke, E. A. (1976). The nature and Causes of job Satisfaction, In M. D. Dunnette, ed., Handbook of Industrial and Organizational Psychology. Chicago: Rand Mcnally.

[33] Luthan, F. (1989). Organizational Behaviour. $5^{\text {th }}$ Ed. New York: Mc Graw Hill Book Company.

[34] Luthans F. (2002). Organization Behavior, $6^{\text {th }}$ Edition, New Jersey, McGraw Hill, Singapore.

[35] McNamara, C. (2008). Employee benefits and compensation: Basics about employee motivation: Nuts-and-Bolts Guide to Leadership and Supervision in Business, Minneapolis, Minnesota: Authenticity Consulting LLC.

[36] Mayuri, B \& Mark, S. N. (2005). Are Higher Pay Increases Necessarily Better? Applied H.R.M. Research, Vol. 10, No. 1, $1-12$.

[37] Melissa, A. (2007). A Report on the Importance of Work-Life Balance, Business

[38] Improvement Architects. [Online]. Available http://www.bia.ca/articles/ AReportontheImportanceofWorkLifeBalance.htm.

[39] Milkovich, G. T., \& Newman, J. M. (2002). Compensation, New York: McGraw Hill.

[40] Michaelowa K. (2002). Teacher Job Satisfaction, Student Achievement, and the Cost of Primary Education in Francophone Sub-Saharan Africa, HWWA Discussion Paper 188.

[41] Millán, José María, Hessels, Jolanda, Thurik, Roy and Aguado Rafael, (2011), Determinants of Job Satisfaction across the $E U-15$ : A Comparison of Self-Employed and Paid Employees, Tinbergen Institute Discussion Paper.

[42] Mokaya, S., Musau, J. and Karanja, K. Effects of Working Conditions on Employee Satisfaction in Hotel Industry in Kenya. International journal of Arts and Commerce Vol. 2 No. 2

[43] Mugenda, O. M. \& Mugenda, G. A. (2003). Research Methods. Quantitative and Qualitative Approaches. Nairobi: Acts press.

[44] Mulvey, P. W., Le Blanc, P. V., Heneman, R. L \& McInerney, M. (2002). The Knowledge of Pay Study: E-mails from the Frontline, Worldatwork, Scottsdale, AZ,

[45] Okumbe, J. A, (1999). Educational Management Theory and Practice. Nairobi, Kenya, Nairobi University Press, Nairobi.

[46] Odunlade, R. O. (2012). Managing Employee Compensation and Benefits for Job Satisfaction in Libraries and Information Centres in Nigeria. Available http://unllib.unl.edu/LPP/

[47] Padilla, V. D. (1993).Job Satisfaction of Vocational Teacher in Puerto Rico. Phd. Thesis. The Ohio State University. 
[48] Patrick, J. (2000). Training, in Chmiel, N. (Eds), Introduction to Work and Organizational Psychology, Blackwell, Oxford, pp.100-25.

[49] Popoola, S. O., Ayeni, C. O., (2007) Work Motivation, Job Satisfaction, and Organisational Commitment of Library Personnel in Academic and Research Libraries in Oyo State, Nigeria. Library Philosophy and Practice.

[50] Pouliakas, K. (2010). Pay Enough, Don't Pay Too Much or Don't Pay at All? The Impact of Bonus Intensity on Job Satisfaction. Kyklos, 63(4), 597-626. doi:10.1111/j.14676435.2010 .00490

[51] Rosenholtz, S. (1999). Teachers' Workplace: The Social Organization of Schools. New York: Teachers College Press.

[52] Sinclair, M. 2002. Planning Education in and after Emergencies. Paris: UNESCO, IIEP.

[53] Smith, A. \& Smith, E. (2007). The Role of Training in the Development of Human Resource Management in Australian Organisations, Human Resource Development International, Vol. 10 No.3, pp.263-79.

[54] Schuster, J. R. \& Zingheim, P. K. (1993). New Pay: Strategies that Work, Journal of Compensation and Benefits, 5-9.
[55] Society for Human Resource Management (2012). Employee Job Satisfaction and Engagement. A research report by SHRM. Retrieved from www.shrmstore. shrm.org.

[56] Sousa-Poza A. A. (2000). Well-being at Work A CrossNational Analysis of the Levels and Determinants of Job Satisfaction, Journal Socio-Economics, Vol.12: 517-538.

[57] Teacher's Service Commission (1986). Code of Regulations for Teachers. Nairobi T. S. C.

[58] Thierry, H. (2001), The Reflection Theory on Compensation, in Erez, M., Kleinbeck, U., Thierry, H. (Eds),Work Motivation in the Context of a Globalizing Economy, Laurence Erlbaum Associates, Mahwah, NJ, pp.149-66.

[59] Uppal, S. (2005). Disability, Workplace Characteristics and Job Satisfaction, International Journal of Manpower, Vol. 26, No. 4.

[60] Wren, D. A. (1994). The evolution of management thought. (4th ed.) New York: Wiley.

[61] Yamoah, E. E. (2013). Reward Systems and Teachers' Performance: Evidence from Ghana, Canadian Social Science, Vol.9, No. 5, pp. 57-62. 